\title{
ABC Transporters in Prorocentrum lima and Their Expression Under Different Environmental Conditions Including Okadaic Acid Production
}

\author{
Song Gu, Shao-Wen Xiao, Jian-Wei Zheng, Hong-Ye Li, Jie-Sheng Liu and Wei-Dong Yang * \\ Key Laboratory of Eutrophication and Red Tide Prevention of Guangdong Higher Education Institutes, \\ College of Life Science and Technology, Jinan University, Guangzhou 510632, China; koosle@163.com (S.G.); \\ swxjbl@126.com (S.-W.X.); jwzheng89@126.com (J.-W.Z.); thyli@jnu.edu.cn (H.-Y.L.); tjsliu@jnu.edu.cn (J.-S.L.) \\ * Correspondence: tywd@jnu.edu.cn; Tel.: +86-20-8522-6386
}

Received: 9 March 2019; Accepted: 27 April 2019; Published: 30 April 2019

\begin{abstract}
Prorocentrum lima is a typical benthic toxic dinoflagellate, which can produce phycotoxins such as okadaic acid (OA). In this study, we identified three $\mathrm{ABC}$ transporter genes ( $A B C B 1, A B C C 1$ and $A B C G 2$ ) and characterized their expression patterns, as well as OA production under different environmental conditions in P. lima. We found that the three $A B C$ transporters all showed high identity with related $A B C$ proteins from other species, and contained classical features of $A B C$ transport proteins. Among them, $A B C G 2$ was a half size transporter. The three $\mathrm{ABC}$ transporter genes displayed various expression profiles under different conditions. The high concentration of $\mathrm{Cu}^{2+}$ could up-regulate $A B C B 1, A B C C 1$ and $A B C G 2$ transcripts in P. lima, suggesting the potential defensive role of $\mathrm{ABC}$ transporters against metal ions in surrounding waters. $\mathrm{Cu}^{2+}$, in some concentration, could induce OA production; meanwhile, tributyltin inhibited OA accumulation. The grazer Artemia salina could induce OA production, and P. lima displayed some toxicity to the grazer, indicating the possibility of $\mathrm{OA}$ as an anti-grazing chemical. Collectively, our results revealed intriguing data about OA production and the expression patterns of three $A B C$ transporter genes. However, we could not find any significant correlation between $\mathrm{OA}$ production and expression pattern of the three $\mathrm{ABC}$ transporters in P. lima. Our results might provide new molecular insights on the defensive responses of $P$. lima to the surrounding environment.
\end{abstract}

Keywords: ABC transporters; Prorocentrum lima; okadaic acid

\section{Introduction}

ATP-binding cassette transporters $(\mathrm{ABC})$ are a large family of membrane proteins with a variety of functions, which exist in almost all organisms [1]. The most common function of $A B C$ transporters is to move multiple substrates into or out of the cytoplasm, such as ions, sugars, amino acids, peptides, toxic metabolites and heterotrophic substances, as well as drugs and toxins [2]. A typical structure of eukaryotic $\mathrm{ABC}$ transporters consists of two conserved structural domains: a transmembrane domain (TMD) and a nucleotide binding domain (NBD) [3]. Based on the protein solubility, TMDs existence, functions and amino acid sequences, $A B C$ transporters have been assigned into eight subfamilies including full size and half size transporters: A, B, C, D, E, F, G, and I [4]. Generally, $\mathrm{ABC}$ transporters in plants are engaged in secondary metabolite transport, heavy metal detoxification, antibiotic transport and phytohormone transport, etc. [5]. Among them, pleiotropic drug resistance (PDR, ABCG), multidrug resistance (MDR, P-glycoprotein, ABCB), and multidrug resistance associated protein (MRP, ABCC) are the well-characterized proteins responsible for chemo-resistance and self-toxicity [6-8]. Therefore, recent studies mainly focused on these three subfamilies. For examples, 
AtMRP6 expression was significantly up-regulated in Arabidopsis thaliana under cadmium stress, and plasma membrane-localized AtPDR8 has been shown to have the capability of mediating $\mathrm{Cd}^{2+}$ efflux, thereby playing a role in cadmium resistance $[9,10]$.

To date, there are few reports about $\mathrm{ABC}$ transporters in algae, and their functions are not well understood. Schulz and Kolukisaoglu, for the first time, proposed that the Chlamydomonas genome consists of about 100 ORFs with domains or proteins similar to $A B C$ transporters [11]. Later on, Merchant et al. put forward that Chlorella contained similar numbers of $\mathrm{ABC}$ transporter families and total $A B C$ transporter genes as a terrestrial plant [12]. However, only 26 kinds of $A B C$ transporters were found in Ceratophyllum demersum, which might contribute to its simpler transport systems, since most $C$. demersum cells have direct access to nutrients in surrounding waters [13]. It was suggested that, in Chlamydomonas, an $\mathrm{ABC}$ transporter was involved in lipid transport between endoplasmic reticulum and chloroplast, as well as in cadmium tolerance [14,15]. In the case of microalgae, Scherer et al., for the first time, confirmed the presence of MRP in diatoms using MK571, a specific inhibitor of MRP [16], while Hou et al. provided evidence for the MRP transporter in the plasma membrane of dinoflagellate [17]. Using gene chip technology, Yang et al. found several ABC transporter genes in the dinoflagellate Alexandrium minutum [18]. Based on the proteomic analysis, Wang et al. found a significantly up-regulated $\mathrm{ABC}$ transporter related protein in strain ACHK-NT, a toxicity-lost mutant of Alexandrium catenella [19]. Interestingly, Carvalho et al. found that expression levels of ABC transporter genes were significantly up-regulated by benzopyrene in Thalassiosira pseudonana [20], indicating the potential role of $\mathrm{ABC}$ transporters defense against environmental pollutants. In aquatic ecosystems, marine microalgae are often exposed to water containing exogenous toxins and harmful substances. Thus, microalgae should have a similar protection or defense system against harmful or cytotoxic substances. Taken together with the roles of ABC transporters in algae tolerance to heavy metals $[14,21]$ and in the microcystin production in Microcystis aeruginosa PCC 7806 [22,23], it is reasonable to speculate that $\mathrm{ABC}$ transporters might have important roles in the transport or sequestration of endogenous secondary metabolites and xenobiotic pollutants. In fact, it has been proposed that $A B C$ transporters export polysaccharides outside of dinoflagellate cells [24]. Nevertheless, to date there is no study available concerning the gene structure and function of $A B C$ transporters in dinoflagellate, despite their biological significance.

Prorocentrum lima is a cosmopolitan epiphytic-benthic toxic dinoflagellate, which often attaches to sand, seaweed, benthic debris and coral reefs on the surface of algae [25]. It has been found that P. lima can produce phycotoxins such as okadaic acid (OA), dinophysistoxin-1 (DTX1), DTX2, and their derivatives, and in turn, associated with DSP episodes in different parts of the world [26]. Tremendous progress towards identifying and assessing toxic components from P. lima have been made, and potential ecological function of OA has been suggested [27-33]. It has been found that OA could decrease the growth rate of Dunaliella tertiolecta and other non-OA producing algae such as D. salina, Thalassiosira weissflogii, Gambierdiscus toxicus and Coolia monotis [30-32]. However, species producing OA were found to be resistant to the deleterious effects of OA [30,31]. This sensitivity of non-OA producing algae to the effect of $\mathrm{OA}$ suggests potential functions of $\mathrm{OA}$ as a deterrent against settlement of other microalgae adjacent to $P$. lima cells or an anti-grazing chemical to prevent other organisms grazing $[31,33]$. However, there is not sufficient evidence supporting these functions of OA, and the biological function of $\mathrm{OA}$ remains elusive.

As described above, $A B C B, A B C C$ and $A B C G$ are involved in many physiological and biochemical processes in various organisms, and play an important role in transmembrane transport of secondary metabolites and exogenous substances, and anti-autotoxicity [34,35]. Some studies have shown that OA in P. lima was compartmentalized in chloroplasts or vacuoles, which could prevent OA from affecting the activity of protein phosphatase in P. lima cells [36-38]. Based on the anti-autotoxicity mechanism of $A B C$ transporters in plant cells, it is speculated that $A B C$ transporters may transport toxic secondary metabolites such as $\mathrm{OA}$ to some organelles to protect itself from harmful effects. 
From the above, we speculate that $\mathrm{ABC}$ transporters might be implicated in transporting or sequestrating endogenous secondary metabolites such as $\mathrm{OA}$ and xenobiotic pollutants like heavy metals, and that OA may function as an anti-grazing chemical to prevent other grazing organisms. The aims of this current study are: (1) to provide information on the character of $A B C$ transporter genes in dinoflagellate and their potential functions in adaption to the surrounding environment in P. lima; (2) to give some evidence for OA as an anti-grazing chemical; and (3) to analyze the potential role of $\mathrm{ABC}$ transporters in $\mathrm{OA}$ transportation in P. lima. For these, complete cDNA sequences of $A B C B 1, A B C C 1$ and $A B C G 2$ in $P$. lima were firstly cloned by RACE, and subsequently, their expression patterns were characterized under different conditions, especially under heavy metal stress. Secondly, P. lima was observed to produce OA production in the presence of Artemia salina, a suitable model species to assess the toxicity of marine benthic dinoflagellates [39]. Finally, given that algal toxin production is governed by multiple intricate physiological and ecological factors, such as the imbalance of nutrient ratio, the availability of nutrients, environmental pollutants, and grazing pressure [40-45], the relationship between the expression of three $\mathrm{ABC}$ genes and $\mathrm{OA}$ production under different conditions (nutrient limitations, different sources of nutrients, heavy metal stress, grazing pressure) was investigated.

\section{Results}

\subsection{Sequence Analysis of $A B C$ s Gene}

The sequences obtained by RACE and local blast were assembled to full-length transcripts of $A B C B 1, A B C C 1$ and $A B C G 2$ in P. lima. The full-length cDNA of $A B C B 1, A B C C 1$ and $A B C G 2$ gene were identified to be 3951, 4259 and 2404 bp, respectively, which have been deposited in NCBI database with the accession numbers (Genbank: MK334304, MK334306 and MK334305). Lengths of open reading frame (ORF) of $A B C B 1, A B C C 1$ and $A B C G 2$ cDNA were found to be 3834, 4098 and $1878 \mathrm{bp}$ in P. lima as deduced by ORF finder (http://www.ncbi.nlm.nih.gov/gorf/gorf.html). Correspondingly, the sizes of predicted protein were $138.3 \mathrm{kDa}(1277 \mathrm{aa}), 147.9 \mathrm{kDa}(1365 \mathrm{aa})$ and $69 \mathrm{kDa}(625 \mathrm{aa})$, and the values of theoretical pI were 5.77, 6.02 and 9.13, respectively. In total, the $5^{\prime}$ - and $3^{\prime}$ - untranslated regions (UTRs) of $A B C B 1, A B C C 1$ and $A B C G 2$ were 60 and $57 \mathrm{bp}, 93$ and $68 \mathrm{bp}, 140$ and $386 \mathrm{bp}$ in P. lima, respectively.

The amino acid sequence analyses showed that the ABCB1 and ABCC1 in P. lima had all typical structural elements of ABC transporters with two TMDs subunits and two NBDs, while the ABCG2 had only one TMD and one NBD. However, all the NBDs contained typical and highly conserved motifs of $A B C$ transporters including Walker $A$, Walker $B, A B C$ signatures and A loops upstream of the Walker A regions (Figure 1). Polyphobius algorithm analyses demonstrated that twelve putative transmembrane helices existed in the ABCB1 transporters, associated with two TMDs with each containing six transmembrane helices, but there were nine and six putative transmembrane helices in ABCC1 transporter and ABCG2 transporter, respectively (Figure 1). Subcellular localization analyses predicted that the three $A B C$ transporters were all located on the cytoplasmic membrane by using CELLO [46], targetP v1.1 [47], ProtComp 9.0 and Euk-mPLoc 2.0 [48] (Supplementary Table S1).

Amino acid sequences of $\mathrm{ABCB} 1, \mathrm{ABCC} 1$ and $\mathrm{ABCG} 2$ in P. lima matched closely to ABCB1, $A B C C 1$ and ABCG2 proteins from various organisms by NCBI BLASTp (Supplementary Figures S1-S3). Phylogenetic analyses of ABCB1/MDR1 transporters from different organisms revealed that the ABCB1/MDR1 proteins from P. lima and Symbiodinium microadriaticum showed the closest relationship, forming an independent branch, then clustering into the other branch containing Fistulifera solaris (Supplementary Figure S4). Similarly, ABCC1 proteins from P. lima had the closest relationship to S. microadriaticum and Tetraselmis sp. GSL018 (Supplementary Figure S5); ABCG2 proteins from P. lima shared the closest relationship with Tetraselmis sp. GSL018, Bathycoccus prasinos and Cyanidioschyzon merolae (strain 10D) (Supplementary Figure S6). 
(A) TMD1 ABCB1 TMD2

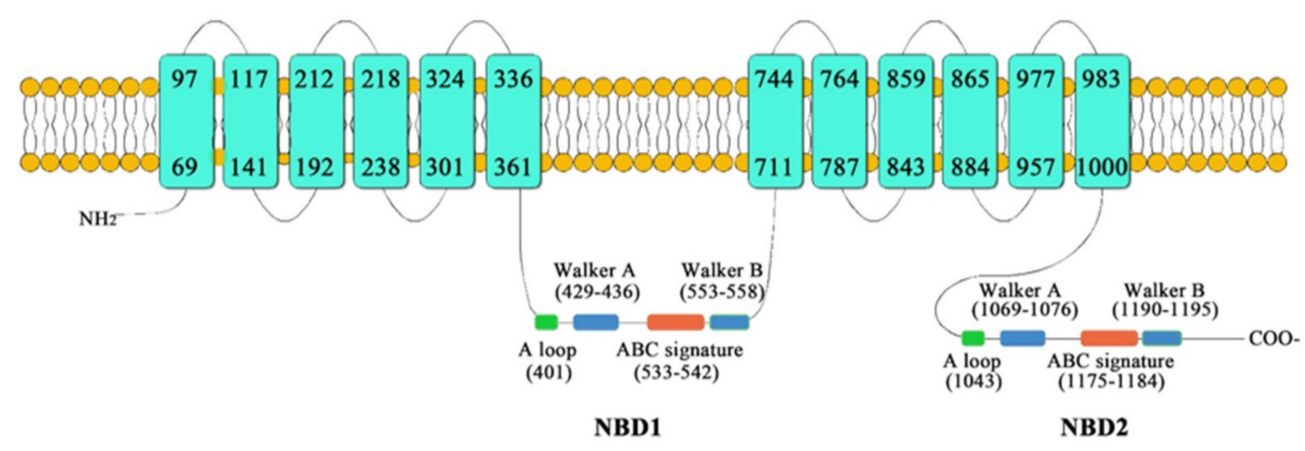

(B) TMD1 ABCC1 TMD2

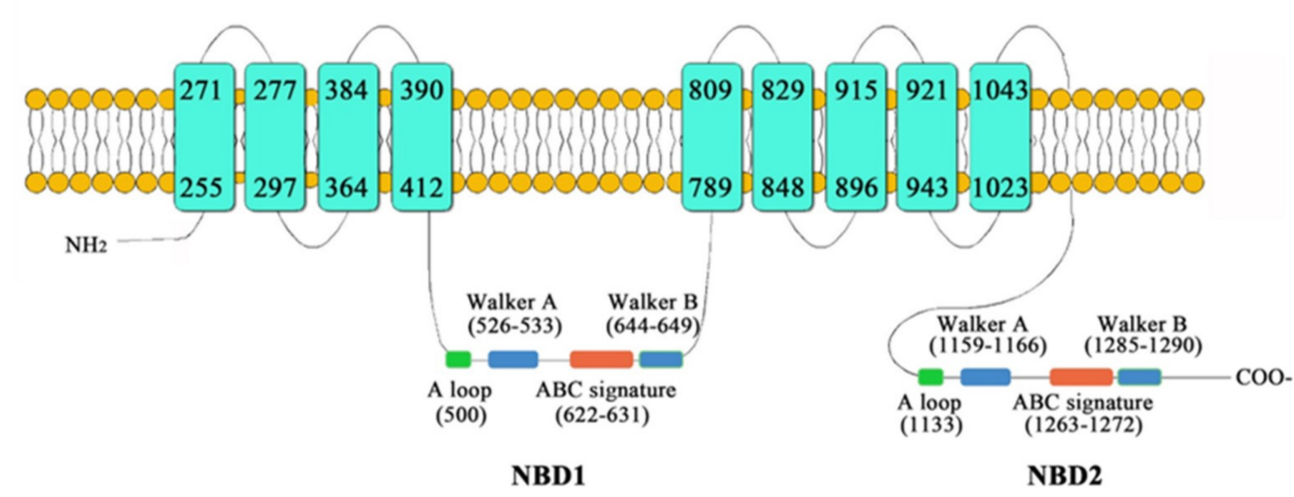

(C)

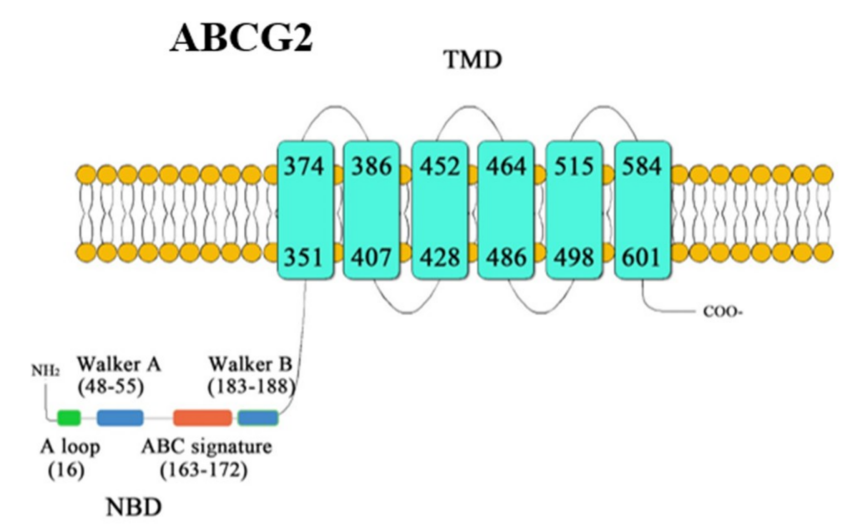

Figure 1. Topologies of ABCB1 (A), ABCC1 (B) and ABCG2 (C) protein in P. lima with transmembrane domains (TMDs) as predicted by the Polyphobius algorithm and nucleotide binding domains (NBDs) indicated by $\mathrm{A}$ loop, Walker $\mathrm{A}$ and $\mathrm{B}$, and the $\mathrm{ABC}$ signature motifs. (A) ABCB1 has two TMDs with 12 transmembrane helices, two NBDs with A loop, Walker A and B, and the $A B C$ signature motifs; (B) ABCC1 has two TMDs with 9 transmembrane helices, two NBDs with A loop, Walker A and B, and the $A B C$ signature motifs; (C) ABCG 2 has one TMD with 6 transmembrane helices, one NBD with A loop, Walker $\mathrm{A}$ and $\mathrm{B}$, and the $\mathrm{ABC}$ signature motifs.

\subsection{Content of $O A$ under Different Conditions}

Tributyltin (TBT) is the most important source of organotin compounds in the marine environment, which has been extensively used as a biocide in anti-fouling paint, commonly known as bottom paint. Studies have shown its deleterious effect on many levels of the ecosystem, including invertebrates and 
vertebrates, even humans [49,50]. As demonstrated in Figure 2, P. lima exhibited differential growth rate under different conditions. N-limitation, P-limitation, $\mathrm{Cu}^{2+}$ and TBT negatively impacted the growth of P. lima. P. lima grew well when $\mathrm{NaH}_{2} \mathrm{PO}_{4}$, glycerophosphate or ATP were provided as phosphorus sources, and $\mathrm{NaNO}_{3}$ and urea used as nitrogen sources. However, when $\mathrm{NH}_{4} \mathrm{Cl}$ was employed as a nitrogen source, the density of $P$. lima showed a downward trend, suggesting that the growth of P. lima was significantly depressed.

A
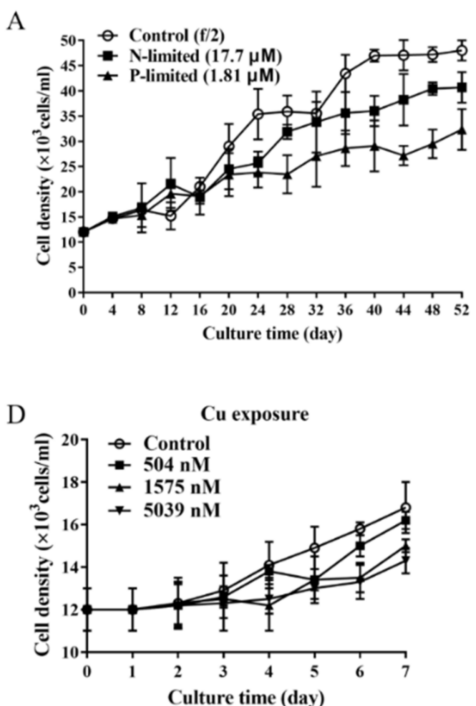

B

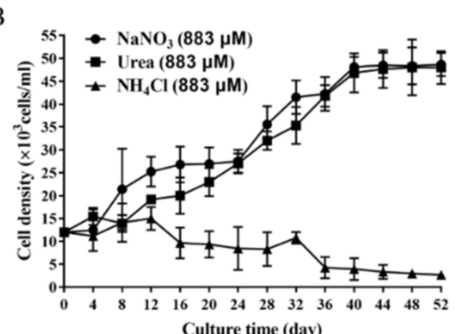

E

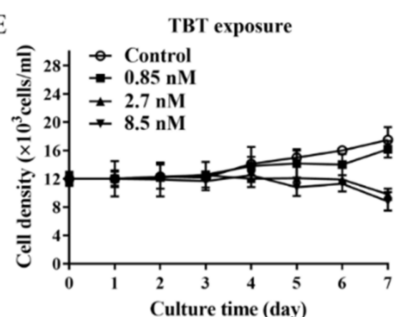

C

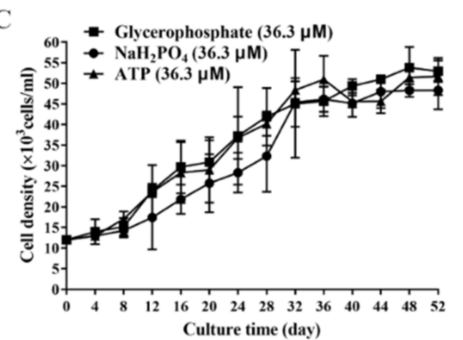

Figure 2. The growth curve of $P$. lima under different environmental conditions. (A) nutrient limitations (N-limited, P-limited); (B) different sources of nitrogen $\left(\mathrm{NaNO}_{3}\right.$, urea and $\left.\mathrm{NH}_{4} \mathrm{Cl}\right) ;(\mathbf{C})$ different sources of phosphorus $\left(\mathrm{NaH}_{2} \mathrm{PO}_{4}\right.$, glycerophosphate and ATP); (D) Cu exposure (504 nM, $1575 \mathrm{nM}$ and 5039 $\mathrm{nM})$; (E) TBT exposure $(0.85 \mathrm{nM}, 2.7 \mathrm{nM}$ and $8.5 \mathrm{nM})$. The values are expressed as mean $\pm \mathrm{SD}(\mathrm{n}=3)$.

OA production varied in different growth phase. The P. lima cells accumulated the most OA during plateau phase (on the 50th day), followed by late logarithmic growth phase (on the 38th day), and exponential phase (on the 20th day). N-limitation, P-limitation, and $\mathrm{Cu}^{2+}$ in $1575 \mathrm{nM}$ and $5039 \mathrm{nM}$ were found to induce OA production in P. lima, while TBT exposure $(2.7 \mathrm{nM}, 8.5 \mathrm{nM})$ decreased OA production (Figure 3A,E,F).

Under different sources of nitrogen, $\mathrm{OA}$ production in the $\mathrm{NH}_{4} \mathrm{Cl}$ group was significantly lower than $\mathrm{NaNO}_{3}(p<0.05)$, but there was no significant difference in OA content between urea group and $\mathrm{NH}_{4} \mathrm{Cl}$ group, as well as between $\mathrm{NaNO}_{3}$ group and urea group (Figure $3 \mathrm{C}$ ). When $\mathrm{NaH}_{2} \mathrm{PO}_{4}$ was used as the phosphorus source, OA production in $P$. lima was significantly reduced with respect to glycerophosphate or ATP as phosphorus sources (Figure 3D).

In the presence of A. salina, the content of OA in P. lima was significantly higher than that of control $(p<0.05)$ (Figure 3B). After $48 \mathrm{~h}$, the survival rate of $A$. salina exposed to P. lima were $72.8 \pm 3.6 \%$, which was distinctly lower than their control counterparts $(91.1 \pm 2.5 \%)$, suggesting the toxicity of $P$. lima to the A. salina. 
A

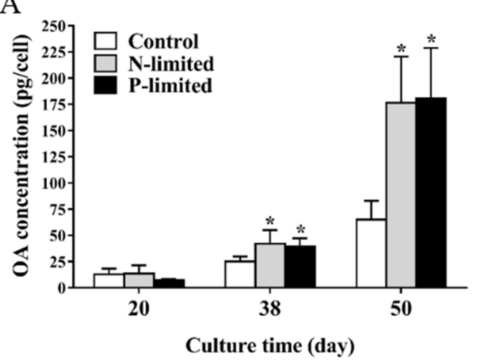

C

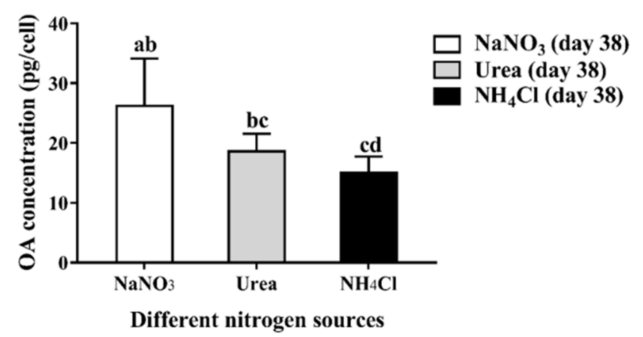

E

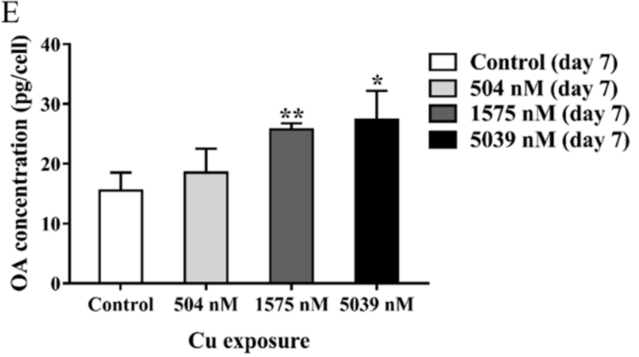

B

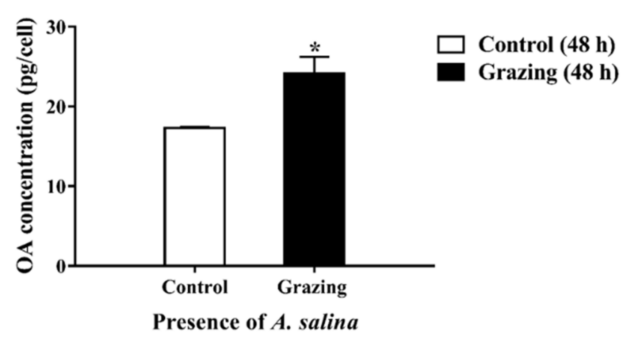

D

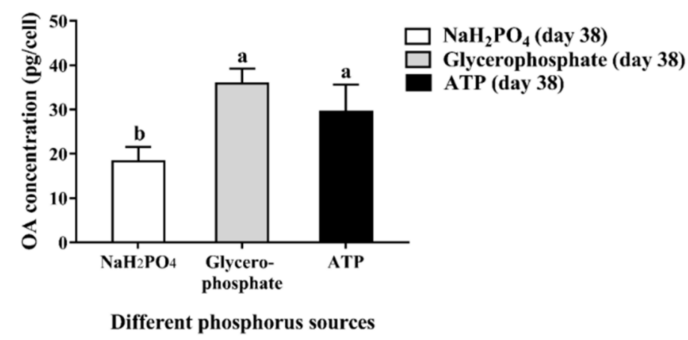

F

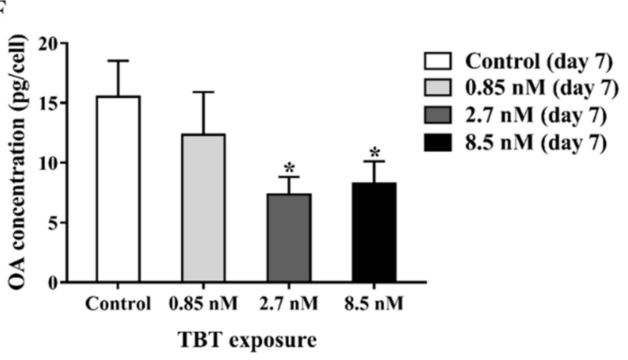

Figure 3. Okadaic acid content (pg cell ${ }^{-1}$ ) in P. lima under different conditions. (A) nutrient limitations; (B) exposure to A. salina; (C) different nitrogen sources; (D) different phosphorus sources; (E) $\mathrm{Cu}$ exposure; F, TBT exposure. The values are expressed as mean $\pm \mathrm{SD}(\mathrm{n}=3)$. In $\mathrm{A}, \mathrm{B}, \mathrm{E}$ and $\mathrm{F}$, asterisks indicate statistically significant differences between control and treatment groups (t-test, $\left.{ }^{*} p<0.05 ;{ }^{* *} p<0.01\right)$. In $\mathrm{C}$ and $\mathrm{D}$, bars of respective treatment followed by the same letter are not significantly different at $p<0.05$ (LSD t-test). In C, OA production in $\mathrm{NH}_{4} \mathrm{Cl}$ group (indicated with cd) was significantly lower than $\mathrm{NaNO}_{3}$ (indicated with $\mathrm{ab}$ ) as nitrogen substrate $(p<0.05)$, but there was no significant difference between urea group (indicated with bc) and $\mathrm{NH}_{4} \mathrm{Cl}$ group (indicated with cd), as well as between $\mathrm{NaNO}_{3}$ group (indicated with $\mathrm{ab}$ ) and urea group (indicated with bc). In D, OA content in $\mathrm{NaH}_{2} \mathrm{PO}_{4}$ group (indicated with b) was significantly lower than glycerophosphate (indicated with a) or ATP (indicated with a) as phosphorus sources, but there was no significant difference between glycerophosphate group (indicated with a) and ATP group (indicated with a).

\subsection{Transcriptional Responses of $A B C B 1, A B C C 1$ and $A B C G 2$ in P. lima under Different Conditions}

As shown in Figure 4, the expression of $A B C B 1, A B C C 1$ and $A B C G 2$ was greatly regulated by specific environmental factors. Under nitrogen or phosphorus-limitation, the expressions of $A B C B 1$ and $A B C G 2$ in P. lima were up-regulated, whereas $A B C C 1$ was significantly reduced $(p<0.05)$ at the 38 th day under N-limited condition (Figure 4A-C). 

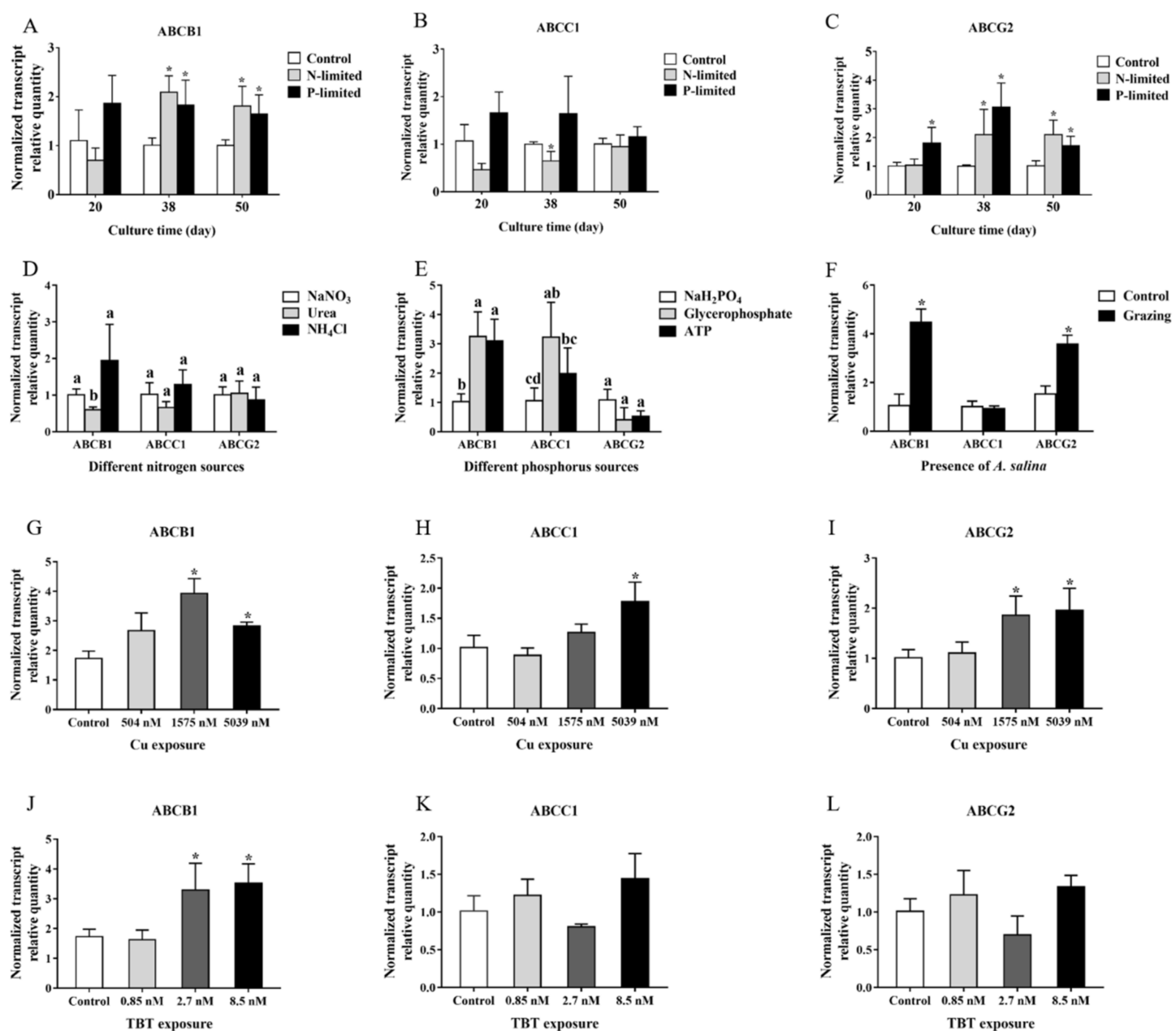

Figure 4. Expression levels of $A B C B 1, A B C C 1$ and $A B C G 2$ mRNA in P. lima under different conditions. (A) $A B C B 1$ under nutrient limitations; (B) $A B C C 1$ under nutrient limitations; (C) $A B C G 2$ under nutrient limitations; (D) $A B C B 1, A B C C 1$ and $A B C G 2$ under different nitrogen sources (day 38; (E) $A B C B 1$, $A B C C 1$ and $A B C G 2$ under different phosphorus sources (day 38); (F) $A B C B 1, A B C C 1$ and $A B C G 2$ in the presence of $A$. salina ( $48 \mathrm{~h}$ ); (G) $A B C B 1$ under $\mathrm{Cu}$ exposure (day 7); (H) $A B C C 1$ under $\mathrm{Cu}$ exposure (day 7); (I) $A B C G 2$ under Cu exposure (day 7); (J) $A B C B 1$ under TBT exposure (day 7); (K) $A B C C 1$ under TBT exposure (day 7); (L) ABCG2 under TBT exposure (day 7). The values are expressed as mean $\pm \mathrm{SD}(\mathrm{n}=3)$. In $\mathrm{A}, \mathrm{B}, \mathrm{C}, \mathrm{F}, \mathrm{G}, \mathrm{H}, \mathrm{I}, \mathrm{J}, \mathrm{K}$ and $\mathrm{L}$, asterisks indicate statistically significant differences between control and treatment groups (t-test, $\left.{ }^{*} p<0.05\right)$. In $\mathrm{D}$ and $\mathrm{E}$, bars of respective treatment followed by the same letter are not significantly different at $p<0.05$ (LSD t-test). In D, $A B C B 1$ transcript abundance when urea as nitrogen (indicated with b) was lower than $\mathrm{NaNO}_{3}$ group (indicated with a) and $\mathrm{NH}_{4} \mathrm{Cl}$ group (indicated with a) $(p<0.05)$. There was no significant difference in $\mathrm{ABCC} 1$ and ABCG2 expression between different groups (all indicated with a). In E, ABCB1 transcript abundance when $\mathrm{NaH}_{2} \mathrm{PO}_{4}$ as phosphorus (indicated with b) was lower than ATP group (indicated with a) and glycerophosphate group (indicated with a) $(p<0.05)$. $\mathrm{ABCC} 1$ expression in $\mathrm{NaH}_{2} \mathrm{PO}_{4}$ group (indicated with cd) was significantly lower than glycerophosphate (indicated with ab) as phosphorus sources, but there was no significant difference between glycerophosphate group (indicated with ab) and ATP group (indicated with $\mathrm{bc}$ ), as well as between $\mathrm{NaH}_{2} \mathrm{PO}_{4}$ group (indicated with cd) and ATP group (indicated with bc). As for ABCG2, there was no significant difference (all indicated with a).

The $P$. lima cells exhibited different expression profiles of $A B C B 1, A B C C 1$ and $A B C G 2$ when cultured under different sources of nitrogen and phosphorus. The expression levels of $A B C B 1$ and $A B C C 1$ were more sensitive to different nitrogen and phosphorus substrates compared to that of $A B C G 2$. $A B C B 1$ transcript abundance in $P$. lima was lower when urea and $\mathrm{NaH}_{2} \mathrm{PO}_{4}$ as nitrogen and phosphorus 
source compared with other nutrient sources assayed (Figure $4 \mathrm{D}$,E). Phosphorus sources displayed some effects on the expression of $A B C C 1$ mRNA in P. lima. ABCC1 performed high expression in $P$. lima when glycerophosphate as phosphorus source, followed by ATP, finally $\mathrm{NaH}_{2} \mathrm{PO}_{4}$ (Figure 4E). As for the $A B C G 2$, it had almost the same expression level in P. lima under different nutrient sources assayed in our study (Figure 4D,E).

$\mathrm{Cu}^{2+}$ in some concentrations distinctly up-regulated the expression of $A B C B 1(1575 \mathrm{nM}, 5039 \mathrm{nM})$, ABCG2 (1575 nM, $5039 \mathrm{nM})$ and $A B C C 1(5039 \mathrm{nM})$ in P. lima (Figure 4G-I). Similarly, TBT exposure could also induce the expression of $A B C B 1$. Under $2.7 \mathrm{nM}$ and $8.5 \mathrm{nM}$ of TBT, the expression of $A B C B 1$ was significantly higher than that of the control (Figure $4 \mathrm{~J}$ ).

In addition, the expressions of $A B C B 1$ and $A B C G 2$ were significantly up-regulated in the presence of A. salina (Figure 4F).

\section{Discussion}

$A B C B 1, A B C C 1$ and $A B C G 2$, i.e., the members of the $\mathrm{ABC}$ transporter family in P. lima obtained in this study, have typical characteristics of their respective sub-families. Consistent with features of ABCB family, ABCB1 protein in P. lima is a full transporter arranged as "TMD-NBD-TMD-NBD", with 12 transmembrane helices and approximately half of $\alpha$-helix. It had highly conserved motifs "Walker $A$ " and "Walker B", and "ABC signature", sharing high homology with other species ABCB1/MDR1 protein. ABCG proteins not only have a full-structured "NBD-TMD-NBD-TMD" molecule, but also have a half-structured "NBD-TMD" molecule [51]. The ABCG2 protein in P. lima is a half-transporter with six transmembrane helices at C-terminus.

ABCC subfamily proteins are full-transporters with diverse functions, such as ion transport and translocation of various xenobiotics and endogenous compounds. As one of long MRPs, ABCC1 has an additional fifth domain, named MSD0 at $\mathrm{N}$ terminus in human [52]. However, ABCC1 protein in P. lima only have two TMDs, with each spanning domain followed by a NBD. Similarly, the dinoflagellate $S$. microadriaticum was proposed to have only 6 transmembrane helices, but Tetraselmis sp. GSL018 have 12 transmembrane helices. The difference in number of transmembrane helices somewhat indicates the complexity of $\mathrm{ABC}$ family in microalgae.

All the ABCBs in Arabidopsis are localized to the plasma membrane. In general, plant ABCB1 are associated with auxin transport, and metal stress tolerance [14]. Similarly, most ABCCs in plants are featured as vacuolar localized proteins, and few have been shown to reside on the plasma membrane [53]. ABCC1 has been demonstrated to be involved in anthocyanin accumulation in vacuoles, and transport of glutathione-conjugates and folate [5]. Half-size ABCGs in plants are localized in the plasma membrane, mitochondrial membrane, chloroplast membrane and cytoplasm. It has been found that ABCG2 is required for synthesis of an effective suberin barrier in roots and seed coats [54]. Based on the sequences obtained, our in silico analyses predicted these three ABC transporters could be localized to the cytoplasmic membrane.

Some studies have shown that OA production in P. lima was increased under nitrogen and phosphorus limitation $[25,27,40]$, and its production was highly varied dependent on the sources of nitrogen and phosphorus $[27,28]$. Consistently, we found that nitrogen and phosphorus limitation could significantly promote the OA production in $P$. lima. OA production was varied under different nitrogen and phosphorus sources. When $\mathrm{NH}_{4} \mathrm{Cl}$ was used as a nitrogen source, the growth rate of P. lima and OA production were significantly decreased compared with other $\mathrm{N}$ substrates, indicating the lethal effect of ammonium at high concentration on P. lima, though it has been proposed to prefer ammonium over other $\mathrm{N}$ substrates in cultures [27].

Heavy metals are usually regarded as a main anthropogenic contaminant in coastal and marine environments all over the world [55], which can also affect the growth and toxin production of dinoflagellate [41-43]. However, not all metal elements could promote the production of microalgae toxins. For example, selenium at $\mathrm{pM}$ level could induce yessotoxin production in Protoceratium reticulatum, but iron and cobalt did not [42]. Tributyltin has been extensively used as a biocide 
in anti-fouling paint, fungicide in agricultural activities, and industrial catalyst in the production of polyurethane foams, etc. As the most important source of organotin compounds in the marine environment, TBT is doomed to be highly persistent due to its reversible adsorption to sediments [50]. Owing to the wide use of $\mathrm{Cu}$ in industrial activities and other fields (as an important ingredient in many algaecides and herbicides), $\mathrm{Cu}$ accumulation in marine sediments has also been becoming a great concern in marine ecosystems [43]. Here, we found that OA production in P. lima was significantly increased under higher concentrations of $\mathrm{Cu}^{2+}(1575 \mathrm{nM}$ and $5039 \mathrm{nM})$, but decreased under higher concentrations of TBT $(2.7 \mathrm{nM}$ and $8.5 \mathrm{nM})$. Copper is one of the most common pollutants in the marine environment, therefore, it should be comprehensively considered when assessing the harmful effects of benthic dinoflagellates.

It has been found that some phycotoxins can function as inducible defensive chemicals against grazing or reducing the number of grazers to ensure that they were not cleared by grazers $[44,56,57]$. Nowadays, numerous studies have shown that this inducible reaction is common in phytoplankton, which can reduce the grazing pressure to maintain the survival of the population $[57,58]$. Selander et al. found that waterborne cues from grazing copepods could increase the cell-specific paralytic shellfish poisoning (PSP) toxin [45]. Dang et al. reported that some grazers could increase the toxicity of K. mikimotoi [44]. Here, we found that OA production in P. lima was significantly increased in the presence of $A$. salina, suggesting the possible anti-grazing role of OA. During the experiment, the survival rate of $A$. salina exposed to $P$. lima was distinctly lower than their control counterparts, which is in line with a previous result on the harmful impact of P. lima on behavior and survival of A. salina [39]. The promotion of grazing pressure on OA production may further increase the accumulation of toxins in the food chain, and increase the risk of toxins.

According to our predictions, the expression levels of $A B C$ transporters varied under different environmental conditions. Nitrogen and phosphorus deficiency induced the expression of $A B C B 1$ and $A B C G 2$ in P. lima. Nitrogen and phosphorus substances, metal ions, and even grazers were shown to regulate the expression of $A B C$ transporters. However, there was no significant correlation observed between the expression of $A B C B 1, A B C C 1$ and $A B C G 2$ genes and OA production. $A B C$ transporters are important carriers for the discharge and compartmentalization of toxic substances and external pollutants, playing an important role in the resistance of algae to secondary metabolites and environmental pollutants [59]. It has been proposed that OA might be synthesized in chloroplast, and stored in chloroplast or vacuoles around the cytoplasm [37]. Furthermore, OA has been confirmed to be eliminated by P-glycoprotein over the apical membrane [60]. The subcellular localization of the three $\mathrm{ABC}$ transporters and the absence of exact correlation between their expressions and OA production seem to diminish the possibility of three transporters transporting OA in P. lima. Nevertheless, DSP toxins-producing dinoflagellate has been shown to secrete toxins into water [61], which suggests the underlying role of the three ABC transporters in transporting DSP toxins from the cells. The production and transportation of DSP toxins in P. lima are very complicated, and more studies are warranted.

Previous studies have shown that $\mathrm{ABC}$ transporters might involve in the detoxification of heavy metals in plants. Gaillard et al. found that AtMRP6 expression was up-regulated in Arabidopsis thaliana under cadmium stress [9]. Lee et al. observed the up-regulation of AtABCG40/AtPDR12 in the shoots of wild plants after exposed to $\mathrm{Pd}^{2+}$, which in turn conferred Pd resistance in Arabidopsis [62]. Kim et al. demonstrated that AtPDR8 localized in the plasma membrane of epidermal cells which mediated $\mathrm{Cd}^{2+}$ efflux by measuring the ${ }^{109} \mathrm{Cd}$ radioactivity in Arabidopsis [10]. In this study, we found that $A B C B 1, A B C C 1$ and $A B C G 2$ transcripts in P. lima were up-regulated at higher $\mathrm{Cu}^{2+}$ concentration, suggesting the potential role of $\mathrm{ABC}$ transporters in detoxification of heavy metals in P. lima. However, the exact role of $\mathrm{ABC}$ transporters in dinoflagellate against metal ion in surrounding waters remains to be investigated. The three $\mathrm{ABC}$ transporters in P. lima might be regulated by various interrelated metabolic changes as in plant [63].

In conclusion, our results demonstrated intriguing data about OA production and expression patterns of various $\mathrm{ABC}$ transporter genes. $\mathrm{Cu}^{2+}$ at some concentrations induced OA production, 
whereas TBT inhibited OA accumulation. The grazer A. salina could induce OA production, and P. lima displayed some toxicity to the grazer, indicating the possible anti-grazing property of OA. Under $\mathrm{N}$ and P-limited conditions, the expression levels of $A B C B 1$ and ABCG2 in P. lima were significantly up-regulated. Nitrogen and phosphorus substrates, metal ions, and even grazer could also regulate the expression of $\mathrm{ABC}$ transporters. However, we could not find any significant correlation between $\mathrm{OA}$ production and the expression of the three $\mathrm{ABC}$ transporters in P. lima, implying the complexity of $\mathrm{OA}$ transportation in P. lima. Higher concentration of $\mathrm{Cu}^{2+}$ could up-regulate $A B C B 1, A B C G 2$ and $A B C C 1$ transcripts in $P$. lima, suggesting the potential role of $A B C$ transporters in dinoflagellate against metal ion in surrounding waters.

\section{Materials and Methods}

\subsection{Algal Culture}

P. lima (CCMP 2579) was kindly provided by National Center for Marine Algae and Microbiota (NCMA, formerly CCMP). The strain was grown as batch cultures in sterile Erlenmeyer flasks containing $\mathrm{f} / 2$ medium, which was filter-sterilized through $0.22-\mu \mathrm{m}$ filters (Jinjing, China). The cultures were grown at $20 \pm 1{ }^{\circ} \mathrm{C}$ in an artificial climate incubator (Jiangnan Instrument Factory, Ningbo, China), where cool-white fluorescent tubes provided an irradiance of $58 \mu \mathrm{mol}$ photons $\mathrm{m}^{-2} \mathrm{~s}^{-1}$ with a 12/12 $\mathrm{h}$ light/dark cycle.

\subsection{Cloning of $A B C$ Transporter Genes}

Algal cells were collected by centrifugation $\left(4500 \times g, 4{ }^{\circ} \mathrm{C}, 2.5 \mathrm{~min}\right)$ from $50 \mathrm{~mL}$ of $P$. lima culture $\left(1.2 \times 10^{7}\right.$ cells $\left./ \mathrm{L}\right)$ after 38 days, then ground to powder in a mortar with liquid nitrogen. Total RNA was extracted with a Hipure Plant RNA Mini kit (Magen, Guangzhou, China) according to the manufacturer's instruction, and retro-transcribed to cDNA using a PrimeScript ${ }^{\mathrm{TM}}$ II 1st Strand cDNA Synthesis kit (TaKaRa, Dalian, China).

Initial cDNA sequences were obtained by comparing $\mathrm{ABC}$ transporter sequences of similar species such as $A B C B 1$ and $A B C C 1$ of Cyanidioschyzon merolae strain 10D and ABCG2 of Tetraselmis sp. GSL018 in GenBank with the Trinity.fasta transcriptome (NCBI database: SRR5,768,053, SRR5,796,841, SRR5,796,842 and SRR5,796,843) of P. lima obtained in our laboratory. Based on the partial sequences obtained, 5'-Full RACE was performed to generate full-length cDNA sequences of $A B C B 1, A B C C 1$ and $A B C G 2$. Related primers for $5^{\prime}$-RACE are listed in Table 1. Touch down PCR was performed and related PCR profiles were as follows: $94{ }^{\circ} \mathrm{C}$ for $3 \mathrm{~min}, 30$ cycles of $94{ }^{\circ} \mathrm{C}(30 \mathrm{~s}), 65^{\circ} \mathrm{C}(30 \mathrm{~s}), 72{ }^{\circ} \mathrm{C}$ ( $2 \mathrm{~min}$ ), followed by 15 cycles of $94{ }^{\circ} \mathrm{C}(30 \mathrm{~s}), 50^{\circ} \mathrm{C}(30 \mathrm{~s})$ and $72{ }^{\circ} \mathrm{C}(2 \mathrm{~min})$, finally $72{ }^{\circ} \mathrm{C}$ for $10 \mathrm{~min}$. Same procedures were performed for $A B C C 1$ and $A B C G 2$. Fragments were purified by using a Gel \& PCR Clean Up kit (Omega, Guangzhou, China), then cloned into the vectors pMD18-T (TaKaRa, Dalian, China) according to the manufacturer's instructions, and sequenced.

Table 1. Primers for 5'-RACE.

\begin{tabular}{|c|c|c|}
\hline Primer Name & Primer Sequence $\left(5^{\prime}-3^{\prime}\right)$ & Target \\
\hline M13-47 & CGCCAGGGTTTTCCCAGTCACGAC & $5^{\prime}-\mathrm{RACE}$ \\
\hline RV-M & GAGCGGATAACAATTTCACACAGG & $5^{\prime}-\mathrm{RACE}$ \\
\hline AAP & CGCGTCGACTAGTACGGGGGGGGGG & $5^{\prime}-\mathrm{RACE}$ \\
\hline AUAP & CGCGTCGACTAGTAC & $5^{\prime}-\mathrm{RACE}$ \\
\hline ABCB1-5GSP1 & GCAGAACCGCACGACGACCT & $5^{\prime}-\mathrm{RACE}$ \\
\hline ABCB1-5GSP2 & GCTCAGACCATGCGCCACAG & $5^{\prime}-\mathrm{RACE}$ \\
\hline ABCC1-5GSP1 & CTGTCATACAGGGGTTGTGGCTCGCTG & $5^{\prime}-\mathrm{RACE}$ \\
\hline ABCC1-5GSP2 & GCTCCAGCTTGCCGGTATCAG & $5^{\prime}-\mathrm{RACE}$ \\
\hline ABCG2-5GSP1 & GCATCCTCTTGTTCCACATACGC & $5^{\prime}-\mathrm{RACE}$ \\
\hline ABCG2-5GSP2 & GACAGTGTTCGCATAGAAGGTG & $5^{\prime}-\mathrm{RACE}$ \\
\hline
\end{tabular}


The sequences were assembled and analyzed by using tools at the Expert Protein Analysis System Server (http://expasy.org/) and NCBI BLAST search engines. TMHMM (http://www.cbs.dtu.dk/services/ $\mathrm{TMHMM} /$ ) was employed to identify transmembrane helices within the amino acid sequences of $\mathrm{ABCB} 1, \mathrm{ABCC} 1$ and $\mathrm{ABCG}$. Subcellular localization of the three $\mathrm{ABC}$ transporters were predicted using CELLO (Xinzhu, Taiwan, China [46], targetP v1.1 [47], ProtComp 9.0 (http://www.softberry. $\mathrm{com} /$ berry.phtml?topic $=$ protcomppl\&group=programs\&subgroup=proloc) and Euk-mPLoc 2.0 [48]. Homology modeling was carried out in term of the amino acid sequences of $A B C B 1, A B C C 1$ and ABCG2 to predict the tertiary structure by using the Swiss-model program (http://swissmodel.expasy.org/). InterPro (http://www.ebi.ac.uk/interpro/) was employed to predict domains of the ABCB1, ABCC1 and ABCG2 amino acid sequences. Transmembrane protein models were mapped using Adobe Photoshop CC 2015 software (https://www.adobe.com/cn/). Multiple sequence alignments and determinations of similarity among amino acid sequences of $\mathrm{ABCB} 1, \mathrm{ABCC} 1$ and $\mathrm{ABCG} 2$ transporters from different organisms were carried out by using Clustal X2 (http://www.clustal.org/clustal2/) and BLAST on NCBI. Phylogenetic trees of $A B C B 1, A B C C 1$ and $A B C G 2$ transporter sequences from different organisms were constructed by Neighbor-joining (NJ) method using MEGA version 7.0 (Philadelphia, PA, USA).

\subsection{Detection of $O A$ in P. lima}

Algal cells were collected by centrifugation $\left(4500 \times g, 4{ }^{\circ} \mathrm{C}, 2.5 \mathrm{~min}\right)$ from $50 \mathrm{~mL}$ of $P$. lima culture, then ground to powder in a mortar with liquid nitrogen. Sequentially, $2 \mathrm{~mL}$ of $80 \%$ methanol was added to the cells and pelleted twice to extract toxins. The supernatant was collected by centrifugation (3000 $\times g$ for $10 \mathrm{~min}$ ) and diluted to $10 \mathrm{~mL}$ with $80 \%$ methanol for OA detection. OA was measured by using an Okadaic Acid (DSP) ELISA test kit (Abraxis, Warminster, PA, USA) according to the manufacturer's instruction.

\subsection{Reverse Transcription-Quantitative PCR (RT-qPCR)}

Expression of $A B C B 1, A B C C 1$ and $A B C G 2$ mRNA in P. lima was evaluated by RT-qPCR. Total RNA was extracted by using a Hipure Plant RNA Mini kit (Magen, Guangzhou, China) according to the manufacturer's instruction. RNA integrity and genome DNA contamination were tested by agarose gel electrophoresis. The concentration and OD260/280 ratio of RNA were evaluated by NanoDrop ${ }^{\circledR}$ ND-1000 (NanoDrop, Waltham, MA, USA). First strand cDNA for each sample was generated from $1 \mu \mathrm{g}$ of total RNA using a HiScript Q RT SuperMix for qPCR (Vazyme, Nanjing, China). Specific primers were designed by using Primer Premier 6.0 (http://www.premierbiosoft.com) (Table 2). The software geNorm (https://genorm.cmgg.be), NormFinder (https://www.moma.dk) and Bestkeeper (https://www.gene-quantification.de/bestkeeper.html) were employed to screen internal genes to normalize expressions of $\mathrm{ABC}$ s from the five common housekeeping genes such as $18 \mathrm{~S}$ RNA, $\beta$-actin, $\beta$-tubulin, GAPDH and Calm. $\beta$-actin and $\beta$-tubulin were chosen as internal genes to normalize expression of target genes due to their most stable expressions.

RT-qPCR was performed in a Bio-Rad CFX96 Real Time PCR System (Bio-Rad, Hercules, CA, USA) with AceQ qPCR SYBR Green Master Mix (Vazyme, Nanjing, China) according to the manufacturers' instructions. PCR profiles were as follows: $95^{\circ} \mathrm{C}$ for $5 \mathrm{~min} ; 40$ cycles of $95^{\circ} \mathrm{C}(30 \mathrm{~s}), 60^{\circ} \mathrm{C}(30 \mathrm{~s}) ; 94{ }^{\circ} \mathrm{C}$ for $15 \mathrm{~s}, 60^{\circ} \mathrm{C}$ for $30 \mathrm{~s}$ and $95^{\circ} \mathrm{C}$ for $15 \mathrm{~s}$.

Relative mRNA expression of ABCs gene in different samples was calculated by formula NRQ [64] with Bio-Rad CFX Manager 3.0 (http://www.advanceduninstaller.com/Bio-Rad-CFX-Manager-3_09f36ee671f747e20a29b7061a3edb5b1-application.htm), in which inter-run calibration algorithms were considered. A standard curve was generated to determine the efficiency of PCR amplification. Amplification efficiency for each reaction was ranged from 0.958 to 1.146 , while the correlation coefficient was ranged from 0.928 to 0.999 . The differences in amplification efficiency between target genes and internal genes were less than $10 \%$. 
Table 2. Specific primers for RT-qPCR used in this paper.

\begin{tabular}{|c|c|c|}
\hline Gene Name & Primer Sequence $\left(5^{\prime}-3^{\prime}\right)$ & Length (bp) \\
\hline \multirow{2}{*}{ ABCB1 } & F: ACGTCGGTGAAGGACAACATC & \multirow{2}{*}{128} \\
\hline & R: CCGACGAAGGTGTTGAACTTC & \\
\hline \multirow{2}{*}{ ABCC1 } & F: ATGTTGACGGCAACGCAGCTC & \multirow{2}{*}{121} \\
\hline & R: AGAAGCTGGAACGTCCACGTG & \\
\hline \multirow{2}{*}{ ABCG2 } & F: AGCATGGTCCGATTGCCATG & \multirow{2}{*}{123} \\
\hline & R: TTAGCTGCCCTGGATCACAC & \\
\hline \multirow{2}{*}{$\beta$-tubulin } & F: GTTGCCTCGTTGTAGTAGACG & \multirow{2}{*}{106} \\
\hline & R: TTTGGGAGGTGATTTCCGACG & \\
\hline \multirow{2}{*}{$\beta$-actin } & F: GCCGACTTCATCTCTGTGTC & \multirow{2}{*}{101} \\
\hline & R: GGCTACTCCTTCACCACTACG & \\
\hline \multirow{2}{*}{$18 \mathrm{~S}$} & F: CCGACTTAGCAGAAGGGTTG & \multirow{2}{*}{104} \\
\hline & R: CAGCAGACGCCATACGACTA & \\
\hline \multirow{2}{*}{ Calm } & F: GCCATGAGGGACAGGAACT & \multirow{2}{*}{131} \\
\hline & R: AAGGAGCTTGGAACCGTGAT & \\
\hline \multirow{2}{*}{ GAPDH } & F: CCCACTCGTTGTCGTACCAG & \multirow{2}{*}{105} \\
\hline & R: CGGATTTCGTGAGCAACAA & \\
\hline
\end{tabular}

\subsection{Expression of $A B C$ Transports in P. lima under Different Conditions}

To learn responses of the three $A B C$ transporter genes to different conditions and to gain information about the relationship between $\mathrm{ABC}$ transporters expression and OA production, four experiments were performed: culture under nutrient-limited conditions (N-limited, P-limited), culture under different sources of nutrients ( $\mathrm{N}$ or $\mathrm{P}$ ), exposure to different heavy metal, and exposure to A. salina. All treatments were performed in triplicate.

I. P. lima under nutrient-limited conditions. P. lima in an initial cell density of $1.2 \times 10^{7}$ cells/L was grown under $\mathrm{N}$-limited conditions (with $\left.17.7 \mu \mathrm{M} \mathrm{NO}_{3}{ }^{-}\right)$, P-limited condition $\left(1.81 \mu \mathrm{M} \mathrm{PO}_{4}{ }^{3-}\right)$ or nutrient-sufficient conditions (with $883.0 \mu \mathrm{M} \mathrm{NO}_{3}{ }^{-}, 36.3 \mu \mathrm{M} \mathrm{PO}_{4}{ }^{3-}$ ). Trace metals and EDTA were at the levels corresponding to $\mathrm{f} / 2$ medium in all cultures. Algal cells were collected on days 20, 38, and 50 for OA extraction, RT-qPCR analysis and morphologic observation, etc.

II. P. lima under different nutrients sources (nitrogen or phosphorus) conditions. P. lima in an initial cell density of $1.2 \times 10^{7}$ cells/L was grown under $883 \mu \mathrm{M}$ of $\mathrm{NaNO}_{3}$, urea or $\mathrm{NH}_{4} \mathrm{Cl}$, where other nutrients were the same as the $\mathrm{f} / 2$ medium. Algal cells were collected on the $38^{\text {th }}$ day for OA detection and RT-qPCR analysis. Similar experiments were performed by employing $\mathrm{NaH}_{2} \mathrm{PO}_{4}$, glycerophosphate or ATP $(36.3 \mu \mathrm{M})$ as sources of phosphorus.

III. P. lima incubated in $\mathrm{f} / 2$ medium with $\mathrm{Cu}^{2+}$ or TBT. P. lima in an initial cell density of $1.2 \times 10^{7}$ cells/L was incubated in $\mathrm{f} / 2$ medium with $\mathrm{Cu}^{2+}(504 \mathrm{nM}, 1575 \mathrm{nM}$ and $5039 \mathrm{nM})$ or TBT $(0.85 \mathrm{nM}$, $2.7 \mathrm{nM}$ and $8.5 \mathrm{nM}$ ) as described Couet et al. [43]. As for the control, $\mathrm{f} / 2$ medium was employed. After 7 days of culture, algal cells were collected for OA detection and RT-qPCR analysis.

IV. P. lima exposure to A. salina. P. lima in an initial cell density of $1.2 \times 10^{7}$ cells/L was cultured in $\mathrm{f} / 2$ medium with or without 180 of $A$. salina as described by Dang et al. [44]. The A. salina individuals were hatched from the spawns, which were purchased from Ocean University of China in Qingdao, China. The animals were cultured in $2000 \mathrm{~mL}$ of seawater sterilized with a salinity of 27 at $20-25^{\circ} \mathrm{C}$ for 7 days, and fed with the green alga Tetraselmis subcordiformis. 
Some viable animals (8.0-10.0 $\mathrm{mm}$ in size) were transferred into fresh $\mathrm{f} / 2$ medium and starved for $72 \mathrm{~h}$ before the experiment. During the experiment, dead A. salina was removed every $24 \mathrm{~h}$ and replaced with healthy and lively $A$. salina individuals. After $48 \mathrm{~h}$, microalgal cells were collected for OA detection and RT-qPCR analysis.

\subsection{Statistical Analyses}

Statistical analyses were carried out by using the software SPSS 19 (Armonk, NY, USA). All data were expressed as mean values \pm standard deviation. Student's t-test with a $95 \%$ confidence interval was used to compare differences between control and treatment groups except for different nutrient sources treatments. LSD t-test was employed to compare differences between means under various nitrogen or phosphorus sources.

Supplementary Materials: The following are available online at http://www.mdpi.com/1660-3397/17/5/259/s1, Figure S1: Alignment of ABCB1 from P. lima with other algae (Tetraselmis sp. GSL018, Fistulifera solaris and Symbiodinium microadriaticum) ABCB1/MDR1 transporter proteins, Figure S2: Alignment of ABCC1 from P. lima with other algae (Cyanidioschyzon merolae strain 10D, Fistulifera solaris, and Symbiodinium microadriaticum) ABCC1/MRP1 transporter proteins, Figure S3: Alignment of ABCG2 from P. lima with other algae (Tetraselmis sp. GSL018, Fistulifera solaris and Symbiodinium microadriaticum) ABCG2 transporter proteins, Figure S4: Phylogenetic tree based on multiple alignment (Clustal X2) of various ABCB1/MDR1 transporter amino acid sequences from various plants and algae, Figure S5: Phylogenetic tree based on multiple alignment (Clustal X2) of various ABCC1/MRP1 transporter amino acid sequences from various plants and algae, Figure S6: Phylogenetic tree based on multiple alignment (Clustal X2) of various ABCG2 transporter amino acid sequences from various plants and algae, Table S1: Subcellular localization of proteins predicted using CELLO (Yu et al, 2014), targetP v1.1 (Emanuelsson et al., 2000), ProtComp 9.0 and Euk-mPLoc 2.0 (Chou and Chen, 2010).

Author Contributions: Conceptualization, W.-D.Y.; methodology, H.-Y.L.; software, J.-W.Z.; validation, W.-D.Y.; formal analysis, S.G. and J.-W.Z.; investigation, S.G. and S.-W.X.; data curation, S.G.; writing-original draft preparation, S.G.; writing-review \& editing, S.G. and W.-D.Y.; supervision, J.-S.L.; project administration, W.-D.Y.; funding acquisition, W.-D.Y.

Funding: This research was funded by the National Natural Science Foundation of China (41576116, 41776120).

Conflicts of Interest: The authors declare no conflict of interest.

\section{References}

1. Rees, D.C.; Johnson, E.; Lewinson, O. ABC transporters: The power to change. Nat. Rev. Mol. Cell Biol. 2009, 10, 218-227. [CrossRef] [PubMed]

2. Davidson, A.L.; Dassa, E.; Orelle, C.; Chen, J. Structure, function, and evolution of bacterial ATP-binding cassette systems. Microbiol. Mol. Biol. Rev. 2008, 72,317-364. [CrossRef]

3. Gottesman, M.M.; Pastan, I. Biochemistry of multidrug resistance mediated by the multidrug transporter. Ann. Rev. Biochem. 1993, 62, 385-427. [CrossRef] [PubMed]

4. Verrier, P.J.; Bird, D.; Burla, B.; Dassa, E.; Forestier, C.; Geisler, M.; Klein, M.; Kolukisaoglu, U.; Lee, Y.; Martinoia, E.; et al. Plant ABC proteins-A unified nomenclature and updated inventory. Trends Plant Sci. 2008, 13, 151-159. [CrossRef] [PubMed]

5. Ofori, P.A.; Mizuno, A.; Suzuki, M.; Martinoia, E.; Reuscher, S.; Aoki, K.; Shibata, D.; Otagaki, S.; Matsumoto, S.; Shiratake, K. Genome-wide analysis of ATP binding cassette (ABC) transporters in tomato. PLoS ONE 2018, 13, e0200854. [CrossRef] [PubMed]

6. Litman, T.; Druley, T.E.; Stein, W.D.; Bates, S.E. From MDR to MXR: New understanding of multidrug resistance systems, their properties and clinical significance. Cell. Mol. Life Sci. 2001, 58, 931-959. [CrossRef] [PubMed]

7. Stukkens, Y.A.; Bultreys, A.; Grec, S.; Trombik, T.; Vanham, D.; Boutry, M. NpPDR1, a pleiotropic drug resistance-type ATP-binding cassette transporter from Nicotiana plumbaginifolia, plays a major role in plant pathogen defense. Plant Physiol. 2005, 139, 341-352. [CrossRef]

8. Nuruzzaman, M.; Zhang, R.; Cao, H.Z.; Luo, Z.Y. Plant pleiotropic drug resistance transporters: Transport mechanism, gene expression, and function. J. Integr. Plant. Biol. 2014, 56, 729-740. [CrossRef] 
9. Gaillard, S.; Jacquet, H.; Vavasseur, A.; Leonhardt, N.; Forestier, C. AtMRP6/AtABCC6, an ATP-binding cassette transporter gene expressed during early steps of seedling development and up-regulated by cadmium in Arabidopsis thaliana. BMC Plant Biol. 2008, 8, 22. [CrossRef]

10. Kim, D.Y.; Bovet, L.; Maeshima, M.; Martinoia, E.; Lee, Y. The ABC transporter AtPDR8 is a cadmium extrusion pump conferring heavy metal resistance. Plant J. 2007, 50, 207-218. [CrossRef]

11. Schulz, B.; Kolukisaoglu, H.U. Genomics of plant ABC transporters: The alphabet of photosynthetic life forms or just holes in membranes? FEBS Lett. 2006, 580, 1010-1016. [CrossRef] [PubMed]

12. Merchant, S.S.; Prochnik, S.E.; Vallon, O.; Harris, E.H.; Karpowicz, S.J.; Witman, G.B.; Terry, A.; Salamov, A.; Fritz-laylin, L.K.; Maréchal-Drouard, L.; et al. The Chlamydomonas genome reveals the evolution of key animal and plant functions. Science 2007, 318, 245-250. [CrossRef] [PubMed]

13. Lane, T.S.; Rempe, C.S.; Davitt, J.; Staton, M.E.; Peng, Y.; Soltis, D.E.; Michael, M.; Deyholos, M.; Leebens-Mack, J.H.; Chase, M.; et al. Diversity of ABC transporter genes across the plant kingdom and their potential utility in biotechnology. BMC Biotechnol. 2016, 16, 47. [CrossRef] [PubMed]

14. Hanikenne, M.; Motte, P.; Wu, M.C.S.; Wang, T.; Loppes, R.; Matagne, R.F. A mitochondrial half-size ABC transporter is involved in cadmium tolerance in Chlamydomonas reinhardtii. Plant Cell Environ. 2005, 28, 863-873. [CrossRef]

15. Benning, C.; Hurlock, A.; Warakanont, J. Lipid transport involving chloroplast envelope membranes in plants and algae. FASEB J. 2015, 29, 366.

16. Scherer, C.; Wiltshire, K.; Bickmeyer, U. Inhibition of multidrug resistance transporters in the diatom Thalassiosira rotula facilitates dye staining. Plant Physiol. Biochem. 2008, 46, 100-103. [CrossRef]

17. Hou, D.Y.; Liang, J.J.; Zou, C.; Li, H.Y.; Liu, J.S.; Yang, W.D. MRP functional activity and character in the dinoflagellate Prorocentrum lima. J. Appl. Phycol. 2016, 28, 1667-1676. [CrossRef]

18. Yang, I.; Beszteri, S.; Tillmann, U.; Cembella, A.; John, U. Growth- and nutrient-dependent gene expression in the toxigenic marine dinoflagellate Alexandrium minutum. Harmful Algae 2011, 12, 55-69. [CrossRef]

19. Wang, D.Z.; Li, C.; Zhang, Y.; Wang, Y.Y.; He, Z.P.; Lin, L.; Hong, H.S. Quantitative proteomic analysis of differentially expressed proteins in the toxicity-lost mutant of Alexandrium catenella (Dinophyceae) in the exponential phase. J. Proteom. 2012, 75, 5564-5577. [CrossRef]

20. Carvalho, R.N.; Bopp, S.K.; Lettieri, T. Transcriptomics responses in marine diatom Thalassiosira pseudonana exposed to the polycyclic aromatic hydrocarbon benzo[a]pyrene. PLoS ONE 2011, 6, e26985. [CrossRef]

21. Wang, T.L.; Wu, M. An ATP-binding cassette transporter related to yeast vacuolar ScYCF1 is important for Cd sequestration in Chlamydomonas reinhardtii. Plant Cell Environ. 2006, 29, 1901-1912. [CrossRef]

22. Tillett, D.; Dittmann, E.; Erhard, M.; von Döhren, H.; Borner, T.; Neilan, B.A. Structural organization of microcystin biosynthesis in Microcystis aeruginosa PCC7806: An integrated peptide-polyketide synthetase system. Chem. Biol. 2000, 7, 753-764. [CrossRef]

23. Pearson, L.A.; Hisbergues, M.; Borner, T.; Dittmann, E.; Neilan, B.A. Inactivation of an ABC transporter gene, mcyH, results in loss of microcystin production in the cyanobacterium Microcystis aeruginosa PCC 7806. Appl. Environ. Microbiol. 2004, 70, 6370-6378. [CrossRef]

24. Gong, W.; Browne, J.; Hall, N.; Schruth, D.; Paerl, H.; Marchetti, A. Molecular insights into a dinoflagellate bloom. ISME J. 2017, 11, 439-452. [CrossRef] [PubMed]

25. Nascimento, S.M.; Purdie, D.A.; Morris, S. Morphology, toxin composition and pigment content of Prorocentrum lima strains isolated from a coastal lagoon in southern UK. Toxicon 2005, 45, 633-649. [CrossRef] [PubMed]

26. Morton, S.L.; Leighfield, T.A.; Haynes, B.L.; Petitpain, D.L.; Busman, M.A.; Moeller, P.D.R.; Bean, L.; Mcgowan, J.; Hurst, J.W., Jr.; Van Dolah, F.M. Evidence of diarrhetic shellfish poisoning along the coast of Maine. J. Shellfish Res. 1999, 18, 681-686.

27. Varkitzi, I.; Pagou, K.; Granéli, E.; Hatzianestis, I.; Pyrgaki, C.; Pavlidou, A.; Montesanto, B.; Economou-Amilli, A. Unbalanced N:P ratios and nutrient stress controlling growth and toxin production of the harmful dinoflagellate Prorocentrum lima (Ehrenberg) Dodge. Harmful Algae 2010, 9, 304-311. [CrossRef]

28. Lee, T.C.; Fong, F.L.; Ho, K.C.; Lee, F.W. The mechanism of diarrhetic shellfish poisoning toxin production in Prorocentrum spp.: Physiological and molecular perspectives. Toxins 2016, 8, 272. [CrossRef]

29. Amar, M.; Aráoz, R.; Iorga, B.I.; Yasumoto, T.; Servent, D.; Molgó, J. Prorocentrolide-A from cultured Prorocentrum lima dinoflagellates collected in Japan blocks sub-types of nicotinic acetylcholine receptors. Toxins 2018, 10, 97. [CrossRef] 
30. Sugg, L.M.; VanDolah, F.M. No evidence for an allelopathic role of okadaic acid among ciguatera-associated dinoflagellates. J. Phycol. 1999, 35, 93-103. [CrossRef]

31. Windust, A.J.; Wright, J.L.C.; McLachlan, J.L. The effects of the diarrhetic shellfish poisoning toxins, okadaic acid and dinophysistoxin-1, on the growth of microalgae. Mar. Biol. 1996, 126, 19-25. [CrossRef]

32. Windust, A.J.; Quilliam, M.A.; Wright, J.L.; McLachlan, J.L. Comparative toxicity of the diarrhetic shellfish poisons, okadaic acid, okadaic acid diol-ester and dinophysistoxin-4, to the diatom Thalassiosira weissflogii. Toxicon 1997, 35, 1591-1603. [CrossRef]

33. Perreault, F.; Matias, M.S.; Oukarroum, A.; Matias, W.G.; Popovic, R. Okadaic acid inhibits cell growth and photosynthetic electron transport in the alga Dunaliella tertiolecta. Sci. Total Environ. 2012, 414, 198-204. [CrossRef]

34. Kamimoto, Y.; Terasaka, K.; Hamamoto, M.; Takanashi, K.; Fukuda, S.; Shitan, N.; Sugiyama, A.; Suzuki, H.; Shibata, D.; Wang, B.; et al. Arabidopsis ABCB21 is a facultative auxin importer/exporter regulated by cytoplasmic auxin concentration. Plant Cell Physiol. 2012, 53, 2090-2100. [CrossRef]

35. Park, J.; Song, W.Y.; Ko, D.; Eom, Y.; Hansen, T.H.; Schiller, M.; Lee, T.G.; Martinoia, E.; Lee, Y. The phytochelatin transporters AtABCC1 and AtABCC2 mediate tolerance to cadmium and mercury. Plant J. 2012, 69, 278-288. [CrossRef] [PubMed]

36. Zhou, J.; Fritz, L. Okadaic acid antibody localizes to chloroplasts in the DSP-toxin-producing dinoflagellates Prorocentrum lima and Prorocentrum maculosum. Phycologia 1994, 33, 455-461. [CrossRef]

37. Barbier, M.; Amzil, Z.; Mondeguer, F.; Bhaud, Y.; Soyer-Gobillard, M.O.; Lassus, P. Okadaic acid and PP2A cellular immunolocalization in Prorocentrum lima (Dinophyceae). Phycologia 1999, 38, 41-46. [CrossRef]

38. Lawrence, J.E.; Cembella, A.D. An immunolabeling technique for the detection of diarrhetic shellfish toxins in individual dinoflagellate cells. Phycologia 1999, 38, 60-65. [CrossRef]

39. Neves, R.A.F.; Fernandes, T.; dos Santos, L.N.; Nascimento, S.M. Toxicity of benthic dinoflagellates on grazing, behavior and survival of the brine shrimp Artemia salina. PLoS ONE 2017, 12, e0175168. [CrossRef]

40. Mclachlan, J.L.; Marr, J.C.; Conlon-Keily, A.; Adamson, A. Effects of nitrogen concentration and cold temperature on DSP-toxin concentrations in the dinoflagellate Prorocentrum lima (prorocentrales, dinophyceae). Nat. Toxins 1994, 2, 263-270. [CrossRef] [PubMed]

41. Maldonado, M.T.; Hughes, M.P.; Rue, E.L.; Wells, M.L. The effect of Fe and Cu on growth and domoic acid production by Pseudo-nitzschia multiseries and Pseudo-nitzschia australis. Limnol. Oceanogr. 2002, 47, 515-526. [CrossRef]

42. Mitrovic, S.M.; Amandi, M.F.; Mckenzie, L.; Furey, A.; James, K.J. Effects of selenium, iron and cobalt addition to growth and yessotoxin production of the toxic marine dinoflagellate Lane Protoceratium reticulatum in culture. J. Exp. Mar. Biol. Ecol. 2004, 313, 337-351. [CrossRef]

43. Couet, D.; Pringault, O.; Bancon-Montigny, C.; Briant, N.; Elbaz, F.P.; Delpoux, S.; Kefidaly, O.Y.; Hela, B.; Charaf, M.; Hervé, F.; et al. Effects of copper and butyltin compounds on the growth, photosynthetic activity and toxin production of two HAB dinoflagellates: The planktonic Alexandrium catenella and the benthic Ostreopsis cf. ovata. Aquat. Toxicol. 2018, 196, 154-167. [CrossRef]

44. Dang, L.; Li, Y.; Liu, F.; Zhang, Y.; Yang, W.; Li, H.; Liu, J. Chemical response of the toxic dinoflagellate Karenia mikimotoi against grazing by three species of zooplankton. J. Eukaryot. Microbiol. 2015, 62, 470-480. [CrossRef]

45. Selander, E.; Cervin, G.; Pavia, H. Effects of nitrate and phosphate on grazer-induced toxin production in "Alexandrium minutum". Limnol. Oceanogr. 2008, 53, 523-530. [CrossRef]

46. Yu, C.S.; Cheng, C.W.; Su, W.C.; Chang, K.C.; Huang, S.W.; Hwang, J.K.; Lu, C.H. CELLO2GO: A web server for protein subCELlular LOcalization prediction with functional gene ontology annotation. PLoS ONE 2014, 9, e99368. [CrossRef] [PubMed]

47. Emanuelsson, O.; Nielsen, H.; Brunak, S.; Heijne, G. Predicting subcellular localization of proteins based on their N-terminal amino acid sequence. J. Mol. Biol. 2000, 300, 1005-1016. [CrossRef]

48. Chou, K.C.; Shen, H.B. A new method for predicting the subcellular localization of eukaryotic proteins with both single and multiple sites: Euk-mPLoc 2.0. PLoS ONE 2010, 5, e9931. [CrossRef]

49. Antizar-Ladislao, B. Environmental levels, toxicity and human exposure to tributyltin (TBT)-contaminated marine environment. A review. Environ. Int. 2008, 34, 292-308. [CrossRef] 
50. Fortibuoni, T.; Noventa, S.; Rampazzo, F.; Gion, C.; Formalewicz, M.; Berto, D.; Raicevich, S. Evidence of butyltin biomagnification along the Northern Adriatic food-web (Mediterranean Sea) elucidated by stable isotope ratios. Environ. Sci. Technol. 2013, 47, 3370-3377. [CrossRef]

51. Hwang, J.U.; Song, W.Y.; Hong, D.; Ko, D.; Yamaoka, Y.; Jang, S.; Yim, S.; Lee, E.; Khare, D.; Kim, K.; Palmgren, M.; et al. Plant ABC transporters enable many unique aspects of a terrestrial plant's lifestyle. Mol. Plant 2016, 9, 338-355. [CrossRef] [PubMed]

52. Chen, Z.S.; Tiwari, A.K. Multidrug resistance proteins (MRPs/ABCCs) in cancer chemotherapy and genetic diseases. FEBS J. 2011, 278, 3226-3245. [CrossRef] [PubMed]

53. Pang, K.; Li, Y.; Liu, M.; Meng, Z.; Yu, Y. Inventory and general analysis of the ATP-binding cassette (ABC) gene superfamily in maize (Zea mays L.). Gene 2013, 526, 411-428. [CrossRef]

54. Yadav, V.; Molina, I.; Ranathunge, K.; Castillo, I.Q.; Rothstein, S.J.; Reed, J.W. ABCG transporters are required for suberin and pollen wall extracellular barriers in Arabidopsis. Plant Cell 2014, 26, 3569-3588. [CrossRef] [PubMed]

55. Yu, R.L.; Yuang, X.; Zhao, Y.H.; Hu, G.R.; Tu, X.L. Heavy metal pollution in intertidal sediments from Quanzhou Bay. Chin. J. Environ. Sci. 2008, 20, 664-669. [CrossRef]

56. Ianora, A.; Bentley, M.G.; Caldwell, G.S.; Casotti, R.; Cembella, A.D.; Engström-Öst, J.; Halsband, C.; Sonnenschein, E.; Legrand, C.; Llewellyn, C.A.; et al. The relevance of marine chemical ecology to plankton and ecosystem function: An emerging field. Mar. Drugs 2011, 9, 1625-1648. [CrossRef]

57. Turner, J.T. Planktonic marine copepods and harmful algae. Harmful Algae 2014, 32, 81-93. [CrossRef]

58. Bergkvist, J.; Selander, E.; Pavia, H. Induction of toxin production in dinoflagellates: The grazer makes a difference. Oecologia 2008, 156, 147-154. [CrossRef]

59. Kretzschmar, T.; Burla, B.; Lee, Y.; Martinoia, E.; Nagy, R. Functions of ABC transporters in plants. Essays Biochem. 2011, 50, 145-160. [CrossRef]

60. Ehlers, A.; These, A.; Hessel, S.; Preiss-Weigert, A.; Lampen, A. Active elimination of the marine biotoxin okadaic acid by P-glycoprotein through an in vitro gastrointestinal barrier. Toxicol. Lett. 2014, 225, 311-317. [CrossRef]

61. Windust, A.J.; Hu, T.; Wright, J.L.C.; Quilliam, M.A.; McLachlan, J.L. Oxidative metabolism by Thalassiosira weissflogii (Bacillariophyceae) of a diol-ester of okadaic acid, the diarrhetic shellfish poisoning. J. Phycol. 2000, 36, 342-350. [CrossRef]

62. Lee, M.; Lee, K.; Lee, J.; Noh, E.W.; Lee, Y. AtPDR12 contributes to lead resistance in Arabidopsis. Plant Physiol. 2005, 138, 827-836. [CrossRef]

63. Bienert, M.D.; Baijot, A.; Boutry, M. ABCG transporters and their role in the biotic stress response. In Plant ABC Transporters. Signaling and Communication in Plants; Geisler, M., Ed.; Springer: Cham, Switzerland, 2014; Volume 22, pp. 131-162.

64. Hellemans, J.; Mortier, G.; De Paepe, A.; Speleman, F.; Vandesompele, J. qBase relative quantification framework and software for management and automated analysis of real-time quantitative PCR data. Genome Biol. 2007, 8, R19. [CrossRef] [PubMed]

(C) 2019 by the authors. Licensee MDPI, Basel, Switzerland. This article is an open access article distributed under the terms and conditions of the Creative Commons Attribution (CC BY) license (http://creativecommons.org/licenses/by/4.0/). 